\title{
Determination of Azilsartan Medoximil and Chlorthalidone in tablets exposed to forced degradation by using RP-HPLC.
}

\author{
T Hemant Kumar ${ }^{*}$, Ayesha Begum¹, D Gowri Sankar² \\ ${ }^{1}$ Department of Pharmaceutical Analysis and Quality Assurance, Vignan Institute of Pharmaceutical Technology, \\ Visakhapatnam, India
}

${ }^{2}$ Department of Pharmaceutical Analysis, Andhra University, Visakhapatnam, India

\begin{abstract}
An RP-HPLC method was developed which was simple, specific and precise accurately and was validated for the simultaneous estimation of Azilsartan Medoxomil and Chlorthalidone by following forced degradation studies in pharmaceutical formulation. The method has been developed using Enable C 18G column $(250 \times 4.6 \mathrm{~mm}, 0.5 \mu \mathrm{m})$ and a mobile phase comprising of acetonitrile and $0.1 \%$ trifluoroacetic acid in water at the ratio of $40: 60 \% \mathrm{v} / \mathrm{v}$ with a flow rate of $0.8 \mathrm{~mL} / \mathrm{min}$. UV detection was carried out at $240 \mathrm{~nm}$. The retention time for Azilsartan Medoxomil and Chlorthalidone were found to be 6.982 and $7.748 \mathrm{~min}$ respectively. The proposed method was validated for various parameters like linearity, range, accuracy, precision, robustness, LOD and LOQ. Linearity was observed over a concentration range 5-80 $\mu \mathrm{g} / \mathrm{ml}$ for Azilsartan Medoxomil $\left(r^{2}=0.9995\right)$ and $2.5-25 \mu \mathrm{g} / \mathrm{ml}$ for Chlorthalidone $\left(\mathrm{r}^{2}=\mathbf{0 . 9 9 7 3}\right)$. The\% RSD for Intraday and Interday precision was found as 0.41 and 0.41 for Azilsartan Medoxomil and 0.32 and 0.47 for Chlorthalidone respectively. The LOD and LOQ were found as $0.0189 \mu \mathrm{g} / \mathrm{ml}$ and $0.0305 \mu \mathrm{g} / \mathrm{ml}$ for Azilsartan Medoxomil and LOD and LOQ were found to be 0.1109 and $0.3522 \mu \mathrm{g} / \mathrm{ml}$ for Chlorthalidone respectively. Azilsartan Medoxomil and Chlorthalidone have been subjected to stress conditions of degradation including acidic, alkaline, oxidative, and thermal and photolysis.
\end{abstract}

Keywords: Azilsartan Medoxomil, Chlorthalidone, RP-HPLC, Forced Degradation.

Accepted on August 08, 2019

\section{Introduction}

Azilsartan Medoxomil (Figure 1) is an Angiotensin II receptor antagonist which has the chemical name (5-Methyl-2-oxo-1,3dioxol-4-yl) methyl 2-ethoxy-1-\{ [2'-(5-oxo-4,5-dihydro 1,2,4oxadiazol-3-yl) biphenyl-4-yl] methyl $\}-1 \mathrm{H}-$ benzimidazole-7carboxylate monopotassium salt. It is a white crystalline powder which is practically insoluble in water but freely soluble solvents like methanol, dimethyl sulfoxide and dimethyl formamide, soluble in acetic acid, slightly soluble in acetone and Acetonitrile and very slightly soluble in Tetra Hydro furan and 1-octanol. It is available in dosages of $40 \mathrm{mg}$ and $80 \mathrm{mg}$, the recommended dosage is $80 \mathrm{mg}$ per day. By hydrolysis of medoxomil ester, the active moiety of Azilsartan Medoxomil can be released. It is an active ARB (AT1) type which is more active in lowering blood pressure within 24 hours when compared to other ARBs. Literature survey shows various analytical methods, either alone or in combination with other drugs includes UV spectrophotometric [1,2], HPLC [3-6], LC-MS [7-10], HPTLC [11] in pure drug, pharmaceutical formulations as well as biological fluids.
Chlorthalidone (Figure 2) is chemically 2-Chloro-5-(1hydroxy-3-oxo-2,3-dihydro-1H-isoindol-1-

yl)benzenesulfonamide. Chlorthalidone is practically insoluble in water, ether and chloroform and soluble in methanol and also slightly soluble in alcohol. It is a thiazide type diuretic used to treat hypertension. It acts in a similar way like the thiazides in causing diuresis but do not possess a benzothiadiazine moiety in it. At the proximal portion of the distal convoluted tubule of the nephron, it shows its action with longest duration of action as compared to other thiazide diuretics. Based on extensive evaluation in clinical trials, the combination of Azilsartan Medoxomil with Chlorthalidone has greater efficacy to other ARBs alone or in combination with hydrochlorothiazide. This advanced efficacy is not offset by a large imbalance in clinically important adverse events [12]. A number of analytical methods have been reported so far for the determination of Chlorthalidone either alone or in combination with other drugs in pure drug, pharmaceutical dosage forms and also in biological samples using spectrophotometry [13,14], HPLC [15-17], GC [18,19] and SFC [20]. The combination of Azilsartan Medoxomil and Chlorthalidone proves effective in the treatment of hypertension. Various other analytical methods have been reported for simultaneous 
estimation of Azilsartan Medoxomil and Chlorthalidone in pure drug, pharmaceutical formulations and biological fluids by spectrophotometric [21] and HPLC [22-26]. From the reported RP-HPLC method for the simultaneous estimation of both drugs in pharmaceutical formulation two methods was stability indicating one but these developed methods showed low linearity range and were less sensitive. As RP-HPLC [27-32] is most commonly used analytical method for estimation of drugs for specificity as well as sensitivity, therefore in the current study an attempt was made to develop a simple, precise, accurate RP-HPLC [33-36] method with forced degradation studies for the analysis of Azilsartan Medoxomil and Chlorthalidone in the pharmaceutical formulation.

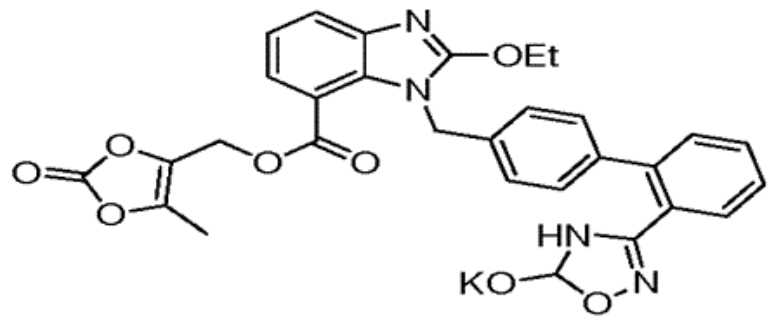

Figure 1. Structure of Azilsartan Medoxomil.

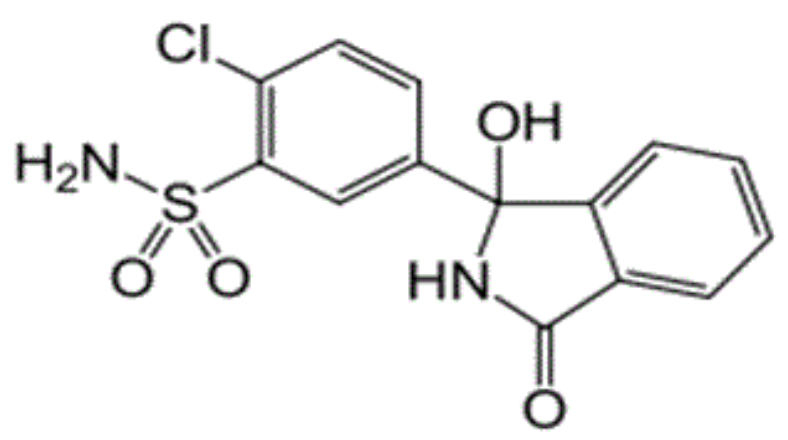

Figure 2. Structure of Chlorthalidone.

\section{Material and Methods}

\section{Materials and chemicals}

Azilsartan Medoxomil and Chlorthalidone standard were obtained from pharma industry, as gifted sample. Azilsartan Medoximil and Chlorthalidone tablets (Edarbychlor Tablets) containing Azilsartan Medoximil $40 \mathrm{mg}$ and Chlorthalidone $12.5 \mathrm{mg}$ were purchased from a pharmacy online. HPLC grade water and acetonitrile was obtained from MERCK India Ltd. HPLC grade methanol was obtained from standard reagent pvt ltd Hyderabad. Analytical grade hydrochloric acid, sodium hydroxide, hydrogen peroxide, trifluroacetic acid, was obtained from SD Fine chemicals Mumbai, India. Nylon membrane filters $0.2 \mu \mathrm{m}$ and $0.45 \mu \mathrm{m}$ were from PALL life sciences Mumbai, India. Ultrasonicator used was from LAB India Ltd Mumbai. pH meter was of Elico LI 120 make. UV Spectrophotometer was of Elico SL 210 model consisted of spectral treats software.

\section{Instrumentation}

The chromatographic system which was used for the method development and validation consisted of Shimadzu HPLC comprising of LC-20AD a binary gradient pump, a SCL 20A system controller, a variable wavelength programmable SPD-20A detector. A Rheodyne injector 7725i was fitted with a $20 \mu \mathrm{L}$ loop which was used and the data was recorded and evaluated by using LC solutions software version 5.0.

\section{Chromatographic conditions}

Chromatographic analysis was performed on Enable C18 G column $(250 \times 4.6 \mathrm{~mm}$ i.d, $5 \mu)$. The mobile phase consisted of acetonitrile and $0.1 \%$ trifluoroacetic acid in water at the ratio of $40: 60 \% \mathrm{v} / \mathrm{v}$. The flow rate was $0.8 \mathrm{~mL} / \mathrm{min}$, injection volume was $20 \mu \mathrm{L}$ and detection was carried out at $240 \mathrm{~nm}$ using a UV detector.

\section{Preparations of Azilsartan Medoxomil and Chlorthalidone stock solution}

Stock solution of Azilsartan Medoximil (1000 $\mu \mathrm{g} / \mathrm{ml})$ and Chlorthalidone $(1000 \mu \mathrm{g} / \mathrm{ml})$ was prepared separately by transferring accurately weighed $50 \mathrm{mg}$ of Azilsartan Medoximil and $50 \mathrm{mg}$ of Chlorthalidone into a $50 \mathrm{ml}$ volumetric flask and to it added a $20 \mathrm{ml}$ methanol. The mixture was sonicated for $5 \mathrm{~min}$ to dissolve the drug and the solution was diluted up to the mark with methanol. To prepare a binary mixture of Chlorthalidone and Azilsartan Medoximil appropriate volume of standard solution was transferred into a $10 \mathrm{ml}$ volumetric flask and diluted with mobile phase to get a solution containing $12.5 \mu \mathrm{g} / \mathrm{ml}$ of Chlorthalidone and $40 \mu \mathrm{g} / \mathrm{ml}$ of Azilsartan Medoximil.

\section{Analysis of Azilsartan Medoxomil and Chlorthalidone in combined dosage form}

Accurately weighed about twenty tablets and average weight of tablet was determined. The tablets were transferred into mortar and triturated to a fine powder form. An a liquate of the powder equivalent to $12.5 \mathrm{mg}$ of Chlorthalidone and $40 \mathrm{mg}$ of Azilsartan Medoximil was transferred into a $100 \mathrm{ml}$ volumetric flask.To it $20 \mathrm{ml}$ HPLC grade methanol was added and sonicated for $5 \mathrm{~min}$ to dissolve the drugs. The content of the flask was kept for $10 \mathrm{~min}$ at laboratory temperature and diluted up to mark with HPLC[37-41] grade methanol this gives a concentration of Chlorthalidone $125 \mu \mathrm{g} / \mathrm{ml}$ and Azilsartan Medoximil $400 \mu \mathrm{g} / \mathrm{ml}$. The above solution was filtered through $0.2 \mu$ membrane filter. The $1 \mathrm{ml}$ of the filtrate was transferred into a $10 \mathrm{ml}$ volumetric flask and diluted with mobile phase to 
get a concentration of $12.5 \mu \mathrm{g} / \mathrm{ml}$ and $40 \mu \mathrm{g} / \mathrm{ml}$ for Chlorthalidone and Azilsartan Medoximil respectively.

\section{Method Validation}

The method was validated for accuracy, precision, linearity, specificity, robustness, limit of detection, limit of quantitation.

\section{Linearity}

Linearity was performed by preparing standard solutions of Chlorthalidone and Azilsartan Medoximil at different concentration levels. Chlorthalidone was prepared in the concentration range of $2.5-25 \mu \mathrm{g} / \mathrm{mL}$ and $5-80 \mu \mathrm{g} / \mathrm{mL}$ for Azilsartan Medoximil. Twenty micro litres of each concentration from both drug solutions was injected in duplicate into the HPLC system. The response was carried out at $240 \mathrm{~nm}$ and the corresponding chromatograms were recorded from these mean peak areas were calculated. The calibration curve was plotted by taking concentration on $\mathrm{x}$-axis and peak areas on $y$-axis for both the drugs.

\section{Accuracy}

The accuracy of the method evaluated by standard addition method in which a known amount of standard drug was added to the fixed amount of pre-analyzed tablet solution. Percent recovery of Chlorthalidone and Azilsartan Medoxomil was calculated at three concentration levels of $80 \%, 100 \%$ and $120 \%$. The solutions were analysed in triplicate at each level. The percent recovery and \%RSD at each level was calculated.

\section{Precision}

Precision of the method was evaluated as system precision and method precision. To study the system precision, six replicate standard solutions of Chlorthalidone and Azilsartan Medoxomil were analysed. The percent relative standard deviation (\% RSD) was calculated for both Chlorthalidone and Azilsartan Medoxomil.

Method precision of the analytical method was carried out on six preparations from the tablet formulation and percentage amount of Chlorthalidone and Azilsartan Medoxomil in the tablet formulation was calculated. The intraday and interday precision study was conducted for both Chlorthalidone and Azilsartan Medoxomil. The mean \% assay value, standard deviation and percent relative standard deviation was calculated.

\section{Limit of detection (LOD) and Limit of quantitation (LOQ)}

LOD was measured by serially diluting the standard solutions of Chlorthalidone and Azilsartan Medoxomil and determining the concentration was response of sample peaks are three times the noise peak. LOQ was measured by serially diluting the standard solutions of Chlorthalidone and Azilsartan Medoxomil and determining the concentration was response of sample peaks are ten times the noise peak.
Robustness: Robustness of the method was determined by making slight changes in composition of organic phase $\pm 5 \%$, flow rate by $\pm 0.1 \mathrm{ml} / \mathrm{min}$ and detection wavelength by $\pm 2 \mathrm{~nm}$.

\section{Specificity}

The specificity of the proposed method was determined against blank and placebo applications. Here mobile phase was used as blank and excipients like starch, lactose, magnesium stearate were used as placebo.

\section{Forced degradation studies}

Different stress conditions were used for the forced degradation studies of formulation. These were also used to evaluate the specificity of the method. All the samples were diluted with mobile phase and filtered through $0.2 \mu$ membrane filter.

\section{Acidic conditions}

Weighed accurately about twenty tablets and triturated it to a fine powder form. An a liquate of the powder equivalent to $12.5 \mathrm{mg}$ of Chlorthalidone and $40 \mathrm{mg}$ of Azilsartan Medoximil was transferred into a $100 \mathrm{ml}$ volumetric flask. To this added a $40 \mathrm{ml}$ of diluent and sonicated for $10 \mathrm{~min}$ to dissolve the drug completely. Then $10 \mathrm{ml}$ of $5 \mathrm{~N} \mathrm{HCl}$ was added to it, refluxed for $6 \mathrm{~h}$ at $60^{\circ} \mathrm{C}$, cooled to room temperature, neutralized with $5 \mathrm{~N} \mathrm{NaOH}$ and diluted up to the mark with the diluent. The above sample solution was filtered through $0.2 \mu$ nylon membrane filter. Pipetted $1 \mathrm{ml}$ of the above filtered sample solution into a $10 \mathrm{ml}$ volumetric flask and volume made up to the mark with diluent.

\section{Alkaline conditions}

Weighed accurately about twenty tablets and triturated it to a fine powder form. An a liquate of the powder equivalent to $12.5 \mathrm{mg}$ of Chlorthalidone and $40 \mathrm{mg}$ of Azilsartan Medoximil was transferred into a $100 \mathrm{ml}$ volumetric flask. To this added a $40 \mathrm{ml}$ of diluent and sonicated for $10 \mathrm{~min}$ to dissolve the drug completely. Then $10 \mathrm{ml}$ of $5 \mathrm{~N} \mathrm{NaOH}$ was added to it, refluxed for $6 \mathrm{~h}$ at $60^{\circ} \mathrm{C}$, cooled to room temperature, neutralized with $5 \mathrm{~N} \mathrm{HCl}$ and diluted up to the mark with the diluent. The above sample solution was filtered through $0.2 \mu$ nylon membrane filter. Pipetted $1 \mathrm{ml}$ of the above filtered sample solution into a $10 \mathrm{ml}$ volumetric flask and volume made up to the mark with diluent.

\section{Oxidative degradation}

Weighed accurately about twenty tablets and triturated it to a fine powder form. An a liquate of the powder equivalent to $12.5 \mathrm{mg}$ of Chlorthalidone and $40 \mathrm{mg}$ of Azilsartan Medoximil was transferred into a $100 \mathrm{ml}$ volumetric flask. To this added a $40 \mathrm{ml}$ of diluent and sonicated for $10 \mathrm{~min}$ to dissolve the drug completely. Then $5 \mathrm{ml}$ of $30 \%$ hydrogen peroxide was added, refluxed for $2 \mathrm{~h}$ at $60^{\circ} \mathrm{C}$, then cooled to room temperature and diluted up to the mark with diluents. The above sample solution was filtered through $0.2 \mu$ nylon membrane filter. 
Pipetted $1 \mathrm{ml}$ of the above filtered sample solution into a $10 \mathrm{ml}$ volumetric flask and volume made up to the mark with diluent.

\section{Thermal degradation}

Weighed accurately about twenty tablets and triturated it to a fine powder form. The powder sample was subjected to thermal stress at $105^{\circ} \mathrm{C}$ for about 2 days. An a liquate of the powder equivalent to $12.5 \mathrm{mg}$ of Chlorthalidone and $40 \mathrm{mg}$ of Azilsartan Medoximil was transferred into a $100 \mathrm{ml}$ volumetric flask. To this added a $20 \mathrm{ml}$ of diluent and sonicated for $10 \mathrm{~min}$ to dissolve the drug completely the diluted up to mark with diluents. The above sample solution was filtered through $0.2 \mu$ nylon membrane filter. Pipetted $1 \mathrm{ml}$ of the above filtered sample solution into a $10 \mathrm{ml}$ volumetric flask and volume made up to the mark with diluent.

\section{Photolytic degradation}

Weighed accurately about twenty tablets and triturated it to a fine powder form. The powder sample was subjected to UV light in a photo stability chamber for about 10 days. An a liquate of the powder equivalent to $12.5 \mathrm{mg}$ of Chlorthalidone and $40 \mathrm{mg}$ of Azilsartan Medoximil was transferred into a 50 $\mathrm{ml}$ volumetric flask. To this added a $40 \mathrm{ml}$ of diluent and sonicated for $10 \mathrm{~min}$ to dissolve the drug completely the diluted up to mark with diluents. The above sample solution was filtered through $0.2 \mu$ nylon membrane filter. Pipetted $1 \mathrm{ml}$ of the above filtered sample solution into a $10 \mathrm{ml}$ volumetric flask and volume made up to the mark with diluent

\section{Results and Discussion}

\section{Optimization of chromatographic conditions}

In the present work an analytical method based on RP-HPLC using UV detector was developed and validated for simultaneous estimation of Chlorthalidone and Azilsartan Medoximil in pharmaceutical formulation. The selection of analytical conditions was based on the chemical nature of Chlorthalidone and Azilsartan Medoximil. A systematic study of various factors were undertaken by varying one parameter at a time and keeping all other conditions constant for development of analytical method. Both Chlorthalidone and Azilsartan Medoximil were soluble in polar solvents therefore RP-HPLC was chosen. The selection of stationary phase has been done on the basis of back pressure, resolution, peak shape, theoretical plates and day to day reproducibility in retention time resolution between Chlorthalidone and Azilsartan Medoximil peaks. After evaluating all these factors Enable $\mathrm{C} 18 \mathrm{G}$ column $(250 \times 4.6 \mathrm{~mm}$ id, $5 \mu)$ was chosen for the analysis. For optimization of mobile phase preliminary trials were conducted under isocratic conditions using mobile phases composed of mixture of solvents like water, methanol, acetonitrile and $0.1 \%$ trifluoroacetic acid in water in different combination. A mixture of acetonitrile and $0.1 \%$ trifluoroacetic acid at a ratio of $40: 60 \% \mathrm{v} / \mathrm{v}$ was found to be most suitable of all the combinations since the chromatographic peaks obtained were have good system suitability parameters. The Flow rate of mobile phase was optimized based on resolution between chromatographic peaks and minimal solvent consumption. The flow rate of mobile phase was changed from $0.5-2 \mathrm{ml} / \mathrm{min}$. It was found from trials that $0.8 \mathrm{ml} / \mathrm{min}$ flow rate was ideal for successful elution of both drugs. For selection of analytical wavelength standard solutions of both drugs were scanned in wavelength range of $200-350 \mathrm{~nm}$. A detection wavelength of $240 \mathrm{~nm}$ was selected. The chromatogram of sample was shown in Figure 3.

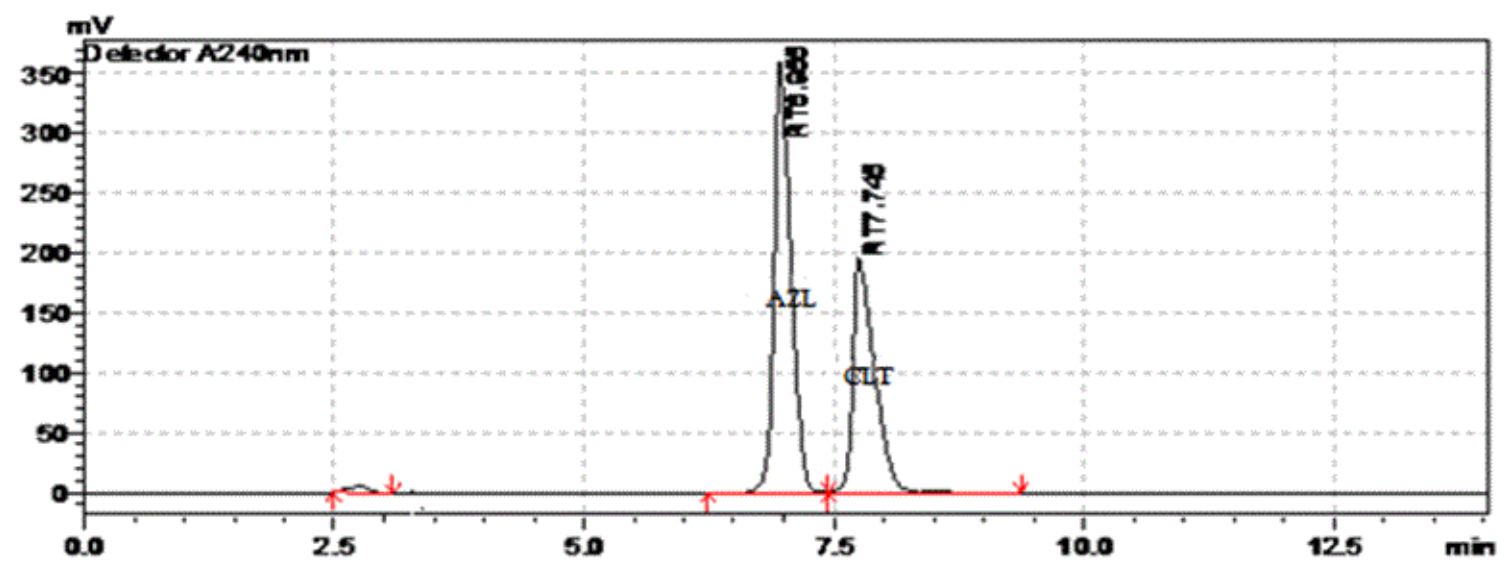

Figure 3. Chromatogram of Azilsartan Medoxomil and Chlorothalidone. 
Determination of Azilsartan Medoximil and Chlorthalidone in tablets exposed to forced degradation by using RP$H P L C$

\section{Method validation}

Linearity: Linearity was studied by preparing standard solutions at different concentration levels. The linearity ranges for Azilsartan Medoxomil and Chlorthalidone were found to be 5-80 $\mu \mathrm{g} / \mathrm{mL}$ and $2.5-25 \mu \mathrm{g} / \mathrm{mL}$ respectively. The linear regression equation for Azilsartan Medoxomil was found to be $167497 x+69323$ with correlation coefficient 0.9995 . The linear regression equation for Chlorthalidone was found to be 234315x-5210.6 with correlation coefficient 0.9973. The calibration table for Azilsartan Medoxomil and Chlorthalidone was shown in Tables 1 and 2 respectively. The calibration curve of Azilsartan Medoxomil and Chlorthalidone were shown in Figures 4 and 5 respectively.

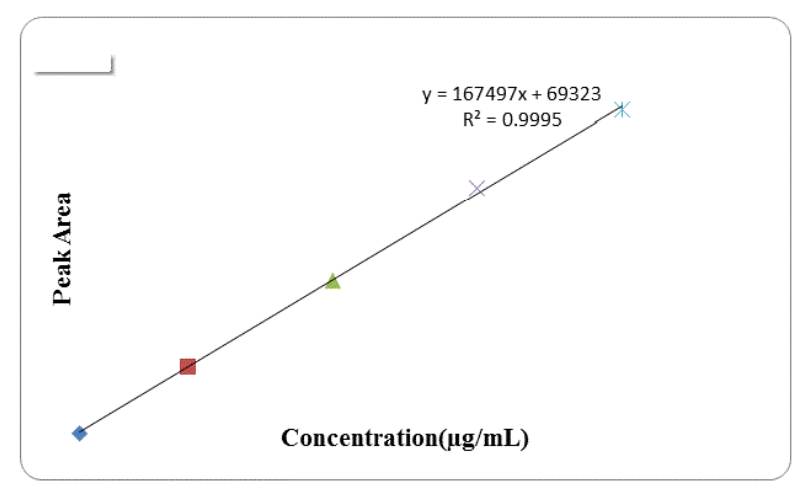

Figure 4. Linearity plot of Azilsartan Medoxomil.



Figure 5. Linearity plot of Chlorthalidone.

Table 1. Linearity data for Azilsartan Medoxomil.

\begin{tabular}{|c|c|c|c|}
\hline Level & $\begin{array}{l}\text { Concentration of } \\
\text { Medoximil }(\mu \mathrm{g} / \mathrm{mL})\end{array}$ & Azilsartan & Mean peak area \\
\hline Level-1 & 5 & & 859346 \\
\hline Level-2 & 20 & & 3438369 \\
\hline Level-3 & 40 & & 6739865 \\
\hline Level-4 & 60 & & 10298508 \\
\hline Level-5 & 80 & & 13347435 \\
\hline Slope & & & 167497 \\
\hline Intercept & & & 69323 \\
\hline \multicolumn{2}{|c|}{ Correlation Coefficient } & & 0.9995 \\
\hline
\end{tabular}

Table 2. Linearity data for Chlorthalidone.

\begin{tabular}{lll}
\hline Level & $\begin{array}{l}\text { Concentration of } \\
\text { Chlorthalidone }(\boldsymbol{\mu g} / \mathrm{mL})\end{array}$ & Mean peak area \\
\hline Level-1 & 2.5 & 586342 \\
\hline Level-2 & 5 & 1162184 \\
\hline Level-3 & 7.5 & 1697926 \\
\hline Level-4 & 10 & 2245369 \\
\hline Level-5 & 12.5 & 2982436 \\
\hline Level-6 & 15 & 3496033 \\
\hline Level-7 & 17.5 & 4295361 \\
\hline Level-8 & 20 & 4753826 \\
\hline Level-9 & 22.5 & 5198043 \\
\hline Level-10 & 25 & 5748645 \\
\hline Slope & & 234315 \\
\hline Intercept & & -5210.6 \\
\hline Correlation Coefficient & & 0.9973 \\
\hline
\end{tabular}

Table 3. Accuracy results of Chlorothalidone.

\begin{tabular}{|c|c|c|c|c|c|}
\hline $\begin{array}{l}\text { Accurac } \\
\text { y level } \\
(\%)\end{array}$ & $\begin{array}{l}\text { Amount } \\
\text { taken }(\mu \mathrm{g} / \mathrm{mL})\end{array}$ & $\begin{array}{l}\text { Amount } \\
\text { found }(\mu \mathrm{g} / \mathrm{mL})\end{array}$ & $\begin{array}{l}\% \\
\text { Recovery }\end{array}$ & $\begin{array}{l}\text { Mean } \\
\text { recovery }\end{array}$ & $\begin{array}{l}\% \\
\text { RSD }\end{array}$ \\
\hline \multirow[t]{3}{*}{80} & 10 & 9.92 & 99.2 & 100.06 & 1.32 \\
\hline & 10 & 10.16 & 101.6 & & \\
\hline & 10 & 9.94 & 99.4 & & \\
\hline \multirow[t]{3}{*}{100} & 12.5 & 12.42 & 99.36 & 99.41 & 0.25 \\
\hline & 12.5 & 12.4 & 99.2 & & \\
\hline & 12.5 & 12.46 & 99.68 & & \\
\hline \multirow[t]{3}{*}{120} & 15 & 15.19 & 101.2 & 100.04 & 1.02 \\
\hline & 15 & 14.93 & 99.53 & & \\
\hline & 15 & 14.91 & 99.4 & & \\
\hline
\end{tabular}

Accuracy: The percent recovery of Chlorthalidone and Azilsartan Medoxomil were found to be $99.41-100.06 \%$ and 99.69-100.1\%.This indicates the accuracy of the method. The results are shown in Tables 3 and 4 .

\section{Precision}

System precision: The \%RSD for Chlorthalidone was found to be 0.91 and for Azilsartan Medoxomil was found to be 1.15 which is within the acceptance criteria of not more than 2.0 indicates the precision of the method (Table 5). 
Table 4. Accuracy results of Azilsartan Medoxomil.

\begin{tabular}{|c|c|c|c|c|c|}
\hline $\begin{array}{l}\text { Accuracy } \\
\text { level (\%) }\end{array}$ & $\begin{array}{l}\text { Amount } \\
\text { taken }(\mu \mathrm{g} / \mathrm{mL})\end{array}$ & $\begin{array}{l}\text { Amount } \\
\text { found }(\mu \mathrm{g} / \mathrm{mL})\end{array}$ & $\begin{array}{l}\text { \% } \\
\text { Recovery }\end{array}$ & $\begin{array}{l}\text { Mean } \\
\text { Recovery }\end{array}$ & $\begin{array}{l}\% \\
\text { RSD }\end{array}$ \\
\hline \multirow[t]{3}{*}{80} & 32 & 32.12 & 100.3 & 99.9 & 0.35 \\
\hline & 32 & 31.89 & 99.65 & & \\
\hline & 32 & 31.92 & 99.75 & & \\
\hline \multirow[t]{3}{*}{100} & 40 & 39.99 & 99.97 & 100.1 & 1.33 \\
\hline & 40 & 39.54 & 98.85 & & \\
\hline & 40 & 40.45 & 101.5 & & \\
\hline \multirow[t]{3}{*}{120} & 48 & 47.89 & 99.77 & 99.69 & 0.21 \\
\hline & 48 & 47.74 & 99.45 & & \\
\hline & 48 & 47.93 & 99.85 & & \\
\hline
\end{tabular}

Table 5. System precision results for Chlorothalidone and Azilsartan Medoxomil.

\begin{tabular}{lll}
\hline Injection No. & $\begin{array}{l}\text { Peak Area } \\
\text { Chlorthalidone }\end{array}$ & $\begin{array}{c}\text { of } \\
\text { Peak Area of } \\
\text { Medoximil }\end{array}$ \\
\hline 1 & 2982436 & 6739865 \\
\hline 2 & 2972874 & 6639284 \\
\hline 3 & 2936438 & 6573948 \\
\hline 4 & 2983931 & 6793842 \\
\hline 5 & 2994725 & 6711174 \\
\hline 6 & 2929373 & 6691059 \\
\hline Mean & 2966630 & 6691529 \\
\hline SD & 27118 & 77130 \\
\hline$\%$ RSD & 0.91 & 1.15 \\
\hline
\end{tabular}

Method precision: The \% RSD for Intraday and Interday precision assay results of six preparations for Chlorthalidone were found to be 0.32 and 0.47 respectively which are within the acceptance criteria of not more than 2.0 indicates the precision of method.

The \% RSD for Intraday and Interday precision assay results of six preparations for Azilsartan Medoxomil were found to be 0.41 and 0.41 respectively which are within the acceptance criteria of not more than 2.0 indicates the precision of the method (Table 6).

Limit of detection and Limit of quantitation: The LOD and LOQ were found to be $0.0189 \mu \mathrm{g} / \mathrm{mL}$ and $0.0305 \mu \mathrm{g} / \mathrm{mL}$ for Azilsartan Medoxomil and the LOD and LOQ for Chlorthalidone were $0.1109 \mu \mathrm{g} / \mathrm{mL}$ and $0.3522 \mu \mathrm{g} / \mathrm{mL}$ respectively.

Robustness: To evaluate the robustness of the developed method, small deliberate variations in optimized method parameters were made.

The effect of change in flow rate, change in composition of mobile phase and detection wavelength on retention time, tailing factor and theoretical plates were studied.

The method was found to be unaffected by small changes in flow rate, change in $\mathrm{pH}$, change in composition of mobile phase and detection wavelength as shown in Tables 7 and 8 .

Table 6. Method precision results for Chlorthalidone and Azilsartan Medoxomil.

\begin{tabular}{lllll}
\hline Set & \multicolumn{2}{l}{ Chlorthalidone $(\%$ Assay) } & $\begin{array}{l}\text { Azilsartan } \\
\text { Assay) }\end{array}$ & Medoximil \\
\hline & Intraday $(\mathrm{n}=6)$ & Interday $(\mathrm{n}=6)$ & Intraday $(\mathrm{n}=6)$ & Interday $(\mathrm{n}=6)$ \\
\hline 1 & 100.13 & 100.51 & 99.48 & 100.03 \\
\hline 2 & 100.08 & 99.59 & 99.39 & 99.54 \\
\hline 3 & 99.85 & 99.86 & 99.34 & 99.61 \\
\hline 4 & 100.18 & 99.38 & 99.81 & 99.83 \\
\hline 5 & 99.34 & 100.49 & 100.07 & 99.37 \\
\hline 6 & 100.04 & 100.16 & 100.32 & 100.48 \\
\hline Mean & 99.93 & 99.99 & 99.73 & 99.81 \\
\hline SD & 0.3134 & 0.4685 & 0.4 & 0.4 \\
\hline$\%$ RSD & 0.32 & 0.47 & 0.41 & 0.41 \\
\hline
\end{tabular}

Table 7. Robustness results for Azilsartan Medoxomil.

\begin{tabular}{|c|c|c|c|}
\hline \multirow[t]{2}{*}{ Conditions } & \multirow[t]{2}{*}{$\%$ Assay } & \multicolumn{2}{|c|}{ System suitability parameters } \\
\hline & & $\begin{array}{l}\text { Theoretical } \\
\text { plates }\end{array}$ & Tailing factor \\
\hline Flow Rate $0.6 \mathrm{~mL} / \mathrm{min}$ & 100.54 & 6996 & 1.08 \\
\hline Flow Rate $1 \mathrm{~mL} / \mathrm{min}$ & 99.48 & 5912 & 1.12 \\
\hline $\begin{array}{l}\text { Mobile Phase-ACN(45): } 0.1 \% \\
\operatorname{TFA}(55)\end{array}$ & 99.79 & 5363 & 1.14 \\
\hline $\begin{array}{ll}\text { Mobile } & \text { Phase-ACN(35): } \\
0.1 \% \operatorname{TFA}(65) & \end{array}$ & 99.34 & 5261 & 1.12 \\
\hline Wavelength $242 \mathrm{~nm}$ & 99.59 & 6980 & 1.11 \\
\hline Wavelength $238 \mathrm{~nm}$ & 99.56 & 6978 & 1.11 \\
\hline
\end{tabular}

Specificity: Specificity is the ability to unequivocally assess the analyte in the presence of components that may be expected to be present. Typically, these might include impurities, degradants or matrix.

Specificity of an analytical method is its ability to accurately and specifically measure the analyte of interest without interference from blank or placebo.

The peak purities of Azilsartan Medoxomil and Chlorthalidone were assessed by comparing the retention times of standard Azilsartan Medoxomil and Chlorthalidone and the sample, and good correlation was obtained between the retention time of the standard and sample.

Placebo and blank were injected and there were no peaks. There is no interference of degradation peaks on drug peaks 
Determination of Azilsartan Medoximil and Chlorthalidone in tablets exposed to forced degradation by using RP-

$H P L C$

hence, the method is specific. The specificity results are shown in Table 9.

Table 8. Robustness results for Chlorothalidone.

\begin{tabular}{|c|c|c|c|}
\hline \multirow[t]{2}{*}{ Conditions } & \multirow[t]{2}{*}{$\%$ Assay } & \multicolumn{2}{|c|}{ System suitability parameters } \\
\hline & & Theoretical plates & Tailing factor \\
\hline Flow Rate $0.6 \mathrm{~mL} / \mathrm{min}$ & 99.56 & 4312 & 1.09 \\
\hline Flow Rate $1 \mathrm{~mL} / \mathrm{min}$ & 99.79 & 4144 & 1.12 \\
\hline $\begin{array}{l}\text { Mobile Phase-ACN(45): } \\
0.1 \% \operatorname{TFA}(55)\end{array}$ & 99.77 & 4352 & 1.12 \\
\hline $\begin{array}{l}\text { Mobile Phase-ACN(35): } \\
0.1 \% \text { TFA(65) }\end{array}$ & 99.84 & 4098 & 1.11 \\
\hline Wavelength $242 \mathrm{~nm}$ & 99.87 & 4107 & 1.12 \\
\hline Wavelength $238 \mathrm{~nm}$ & 99.69 & 4116 & 1.12 \\
\hline
\end{tabular}

Table 9. Specificity results of the method.

\begin{tabular}{ll}
\hline Name of solution & Retention time \\
\hline Blank & No peaks \\
\hline Placebo & $2.743 \mathrm{~min}$ \\
\hline Chlorthalidone & $7.748 \mathrm{~min}$ \\
\hline Azilsartan Medoximil & $6.982 \mathrm{~min}$
\end{tabular}

Analysis of commercial formulation: The proposed method was applied for the determination of Azilsartan Medoxomil and Chlorthalidone in marketed formulations available (Edarbychlor Tablets). The \% recovery was found to be 99.65 \pm 0.86 and $99.76 \pm 0.67$ for Azilsartan Medoxomil and Chlorthalidone respectively (Tables 10 and 11).

Results of forced degradation studies: Under acidic conditions Azilsartan Medoximil degraded to $1.64 \%$ and Chlorthalidone degraded to $0.45 \%$. In these stress conditions there is an appearance of two degradant peaks at retention times of 3.512 and $4.155 \mathrm{~min}$. In basic conditions Azilsartan Medoximil degraded to $16.43 \%$ and Chlorthalidone degraded to $0.46 \%$. Under these conditions there is an appearance of two major peaks and many minor peaks degradation peaks on chromatogram. The retention times of major peaks are at 2.012 min and $3.998 \mathrm{~min}$. In oxidative conditions Azilsartan Medoximil degraded to $2.52 \%$ and Chlorthalidone to $0.31 \%$. There is an appearance of degradant peaks on chromatogram at the retention time of $4.012 \mathrm{~min}$. In thermal conditions Azilsartan Medoximil degraded to $0.17 \%$ and Chlorthalidone degraded to $0.06 \%$. There is no appearance of degradant peaks on chromatogram. In photolytic conditions Azilsartan Medoximil degraded to $1.08 \%$ and Chlorthalidone degraded to $0.82 \%$. There is an appearance of two degradation peaks at the retention time of $3.532 \mathrm{~min}$ and $4.145 \mathrm{~min}$ on chromatogram. From the degradation studies it was concluded that both Chlorthalidone shown stability in all conditions but degraded some extent in photolytic conditions. Azilsartan medoximil shown stability in thermal conditions but in remaining conditions it degraded significantly especially in alkaline conditions (Figures 6-10).

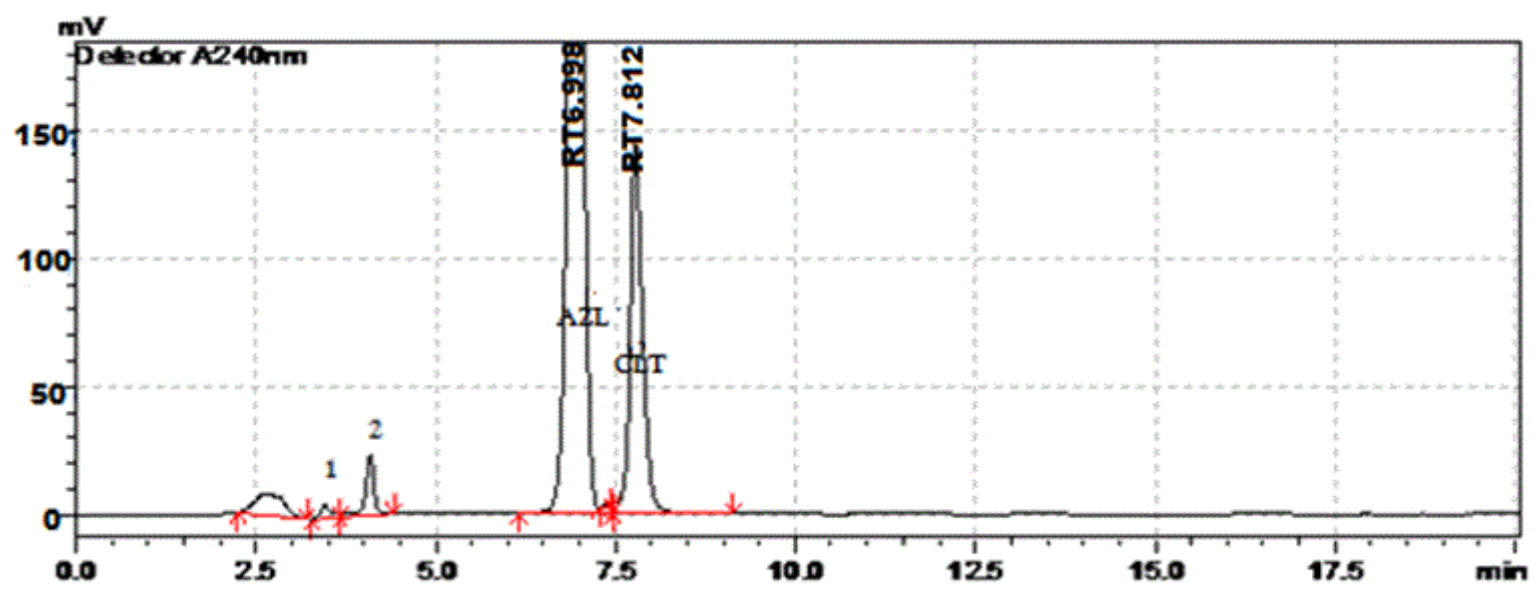

Figure 6. Acid degradation chromatogram.

Table 10. Analysis of Azilsartan Medoxomil and Chlorthalidonein commercial formulation.

\begin{tabular}{llllll}
\hline Formulation & \multicolumn{2}{c}{ Labelled claim $(\mathrm{mg})$} & & Amount found $(\mathbf{m g})$ & $\%$ Recovery $\pm \%$ RSD \\
\cline { 2 - 6 } & Azilsartan Medoximil & Chlorthalidone & $\begin{array}{l}\text { Azilsartan } \\
\text { Medoximil }\end{array}$ & Chlorthalidone & $\begin{array}{c}\text { Azilsartan } \\
\text { Medoximil }\end{array}$ \\
\hline Edarbychlor tablets & 40 & 12.5 & 39.86 & 12.47 & $99.65 \pm 0.86$ \\
\hline
\end{tabular}

*Average of three determinations 


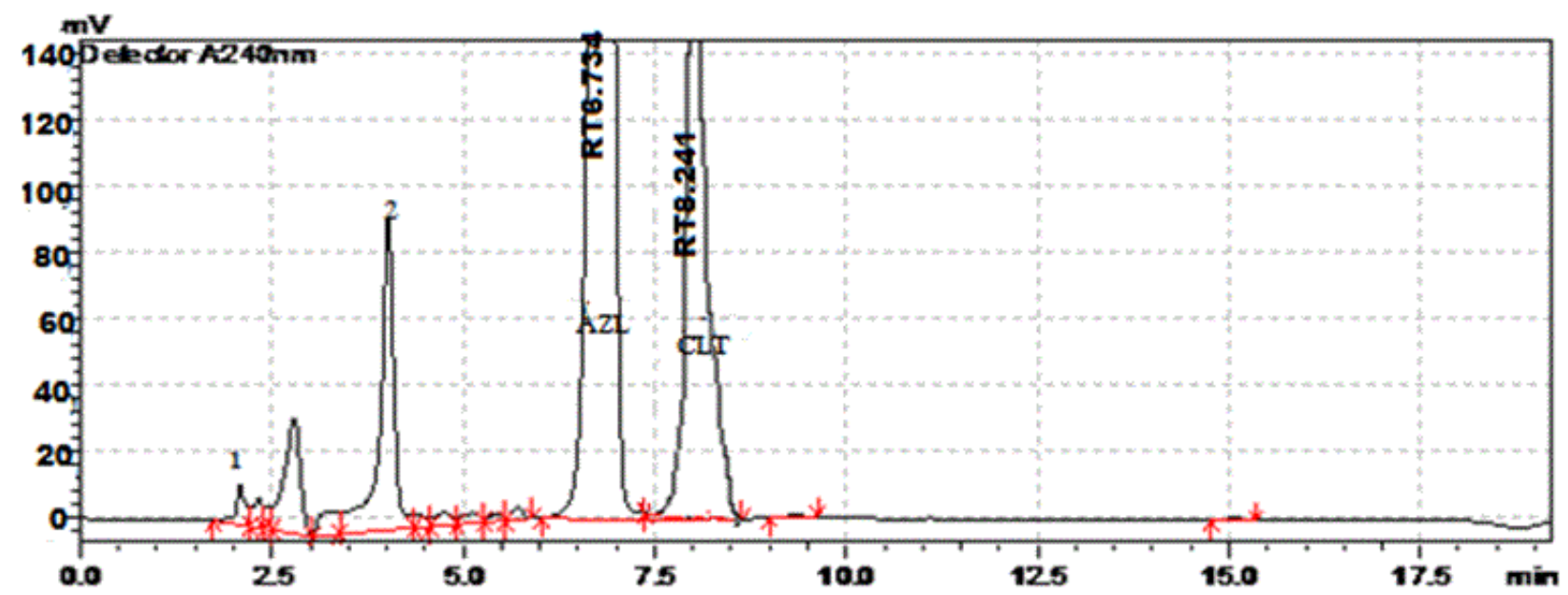

Figure 7. Base degradation chromatogram

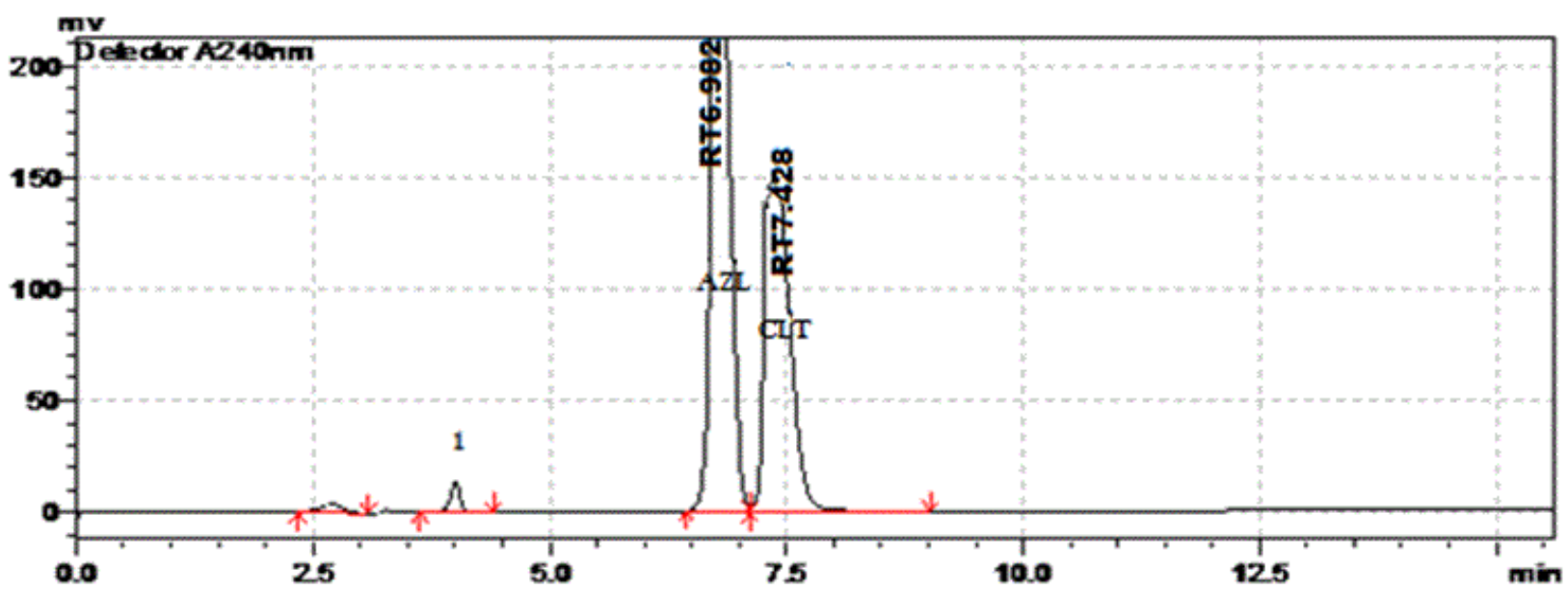

Figure 8. Oxidative degradation chromatogram.

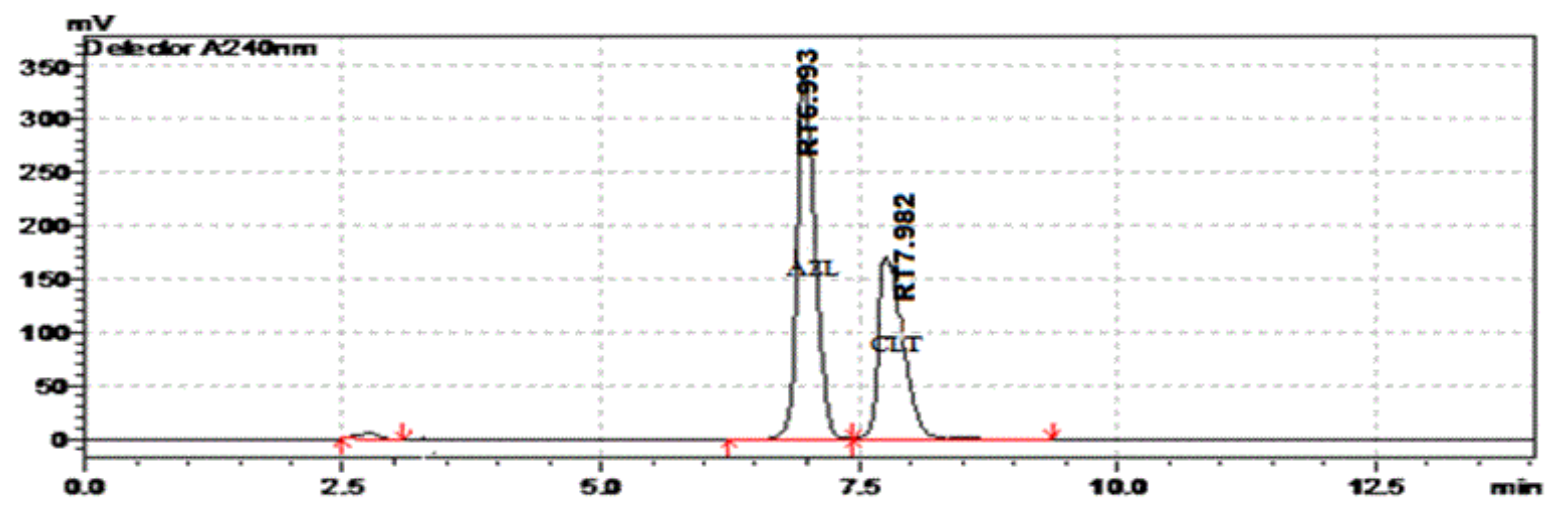

Figure 9. Thermal degradation chromatogram. 


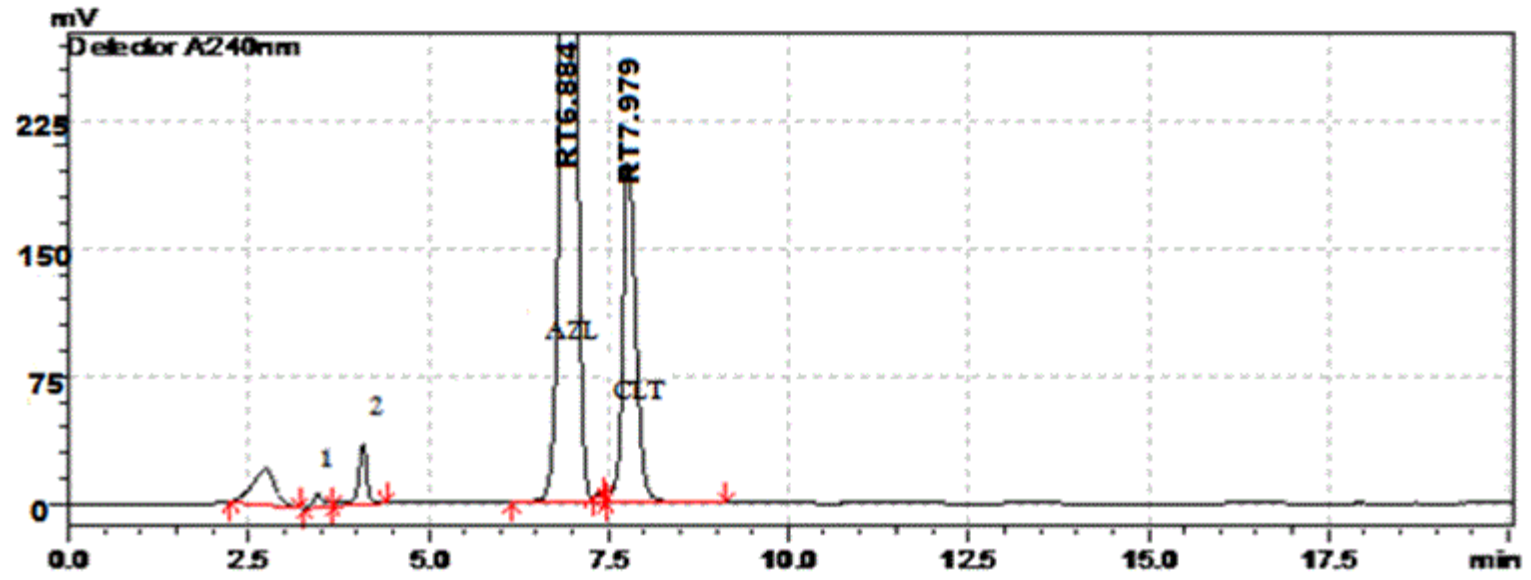

Figure 10. Photolytic degradation chromatogram.

Table 11. Forced degradation studies of Chlorthalidone and Azilsartan Medoxomil.

\begin{tabular}{|c|c|c|c|c|c|c|c|}
\hline Stress Conditions & Duration & $\begin{array}{l}\% \\
\text { recovered }\end{array}$ & Drug & $\%$ Drug decomposed & Retention time (min) & Theoretical plates & $\begin{array}{l}\text { Tailing } \\
\text { factor }\end{array}$ \\
\hline \multicolumn{8}{|l|}{ Chlorthalidone } \\
\hline Control Sample & --- & 99.76 & & --- & 7.748 & 4287 & 1.1 \\
\hline Acid Degradation & $6 \mathrm{~h}$ & 99.26 & & 0.45 & 7.812 & 4596 & 1.15 \\
\hline Alkaline Degradation & $6 \mathrm{~h}$ & 99.29 & & 0.46 & 8.241 & 3990 & 1.05 \\
\hline Oxidative Degradation & $2 \mathrm{~h}$ & 99.39 & & 0.31 & 7.428 & 4261 & 1.42 \\
\hline Thermal Degradation & 2 days & 99.67 & & 0.06 & 7.982 & 3986 & 1.34 \\
\hline Photolytic Degradation & 10 days & 98.92 & & 0.82 & 7.979 & 4984 & 1.11 \\
\hline \multicolumn{8}{|l|}{ Azilsartan Medoximil } \\
\hline Control Sample & ---- & 99.65 & & --- & 6.982 & 6899 & 1.08 \\
\hline Acid Degradation & $6 \mathrm{~h}$ & 98.01 & & 1.64 & 6.998 & 6483 & 1.12 \\
\hline Alkaline Degradation & $6 \mathrm{~h}$ & 82.79 & & 16.43 & 6.734 & 6244 & 1.13 \\
\hline Oxidative Degradation & $2 \mathrm{~h}$ & 97.08 & & 2.52 & 6.982 & 6534 & 1.11 \\
\hline Thermal Degradation & 2 days & 99.26 & & 0.17 & 6.993 & 6623 & 1.09 \\
\hline Photolytic Degradation & 10 days & 98.56 & & 1.08 & 6.884 & 6834 & 1.11 \\
\hline
\end{tabular}

\section{Conclusion}

The proposed method for the simultaneous estimation of Azilsartan Medoxomil and Chlorthalidone validated as per the ICH guidelines and it is simple, specific and reliable. The data generated from the forced degradation studies enabled the evaluation of Azilsartan Medoxomil and Chlorthalidone stability under a variety of ICH recommended conditions. These data are valuable for the safety and potency assessment of a drug product. Furthermore, this simple and rapid RPHPLC method can also be used successfully for the determination of Azilsartan Medoxomil and Chlorthalidone in pharmaceutical formulations without any interference from the excipient.

\section{Acknowledgments}

The authors are grateful to Dr L Rathaiah, Chairman of Lavu educational society for providing necessary facilities to carry out the above research work.

\section{References}

1. Sreenivasulu J, Venkata Ramana P, Sampath Kumar Reddy G, Nagaraju CV, Thirumalai Rajan S, Eswaraiah S. A Rapid Novel HPLC Method for Estimation of Eight 
Related Compounds in Azilsartan Kamedoxomil and Identification of Degradation Compounds by Using LCMS. J Chrom Sci 2015; 53: 1463-1467.

2. Aher SS, Saudagar RB. UV-spectrophotometric method development and validation of azilsartan medoxomil in pharmaceutical dosage form. Wor J Pharm Res 2014; 3: 840-845.

3. Bhaskara PV, Mantena, Sumathi V, Rao, Appa Rao KM, Ramakrishna K, Srikanth R. Method Development and Validation for the Determination of Potential Impurities Present in Azilsartan medoxomil Tablets by Reverse PhaseUltra Performance Liquid Chromatography. Analytical Chemistry Letters 2014; 4-5.

4. Vekariya PP, Joshi HS. Development and validation of RPHPLC method for Azilsartan medoxomil potassium quantitation in human plasma by solid phase extraction procedure. Isrn Spectroscopy 2013.

5. Masthanamma SK. Stability Indicating RP-HPLC method for determination of Azilsartan medoxomil in Pharmaceutical dosage form. Res J Pharm Tech 2014; 7 : 5.

6. Srinivasan R, Chandra JK, Kumar DR, Kumar ND. Stability indicating RP-HPLC method for determination of azilsartan medoxomil in bulk and its dosage form. Int $\mathrm{J}$ Pharm Anal Res 2014; 3: 445.

7. Swain D, Patel PN, Palaniappan I, Sahu G, Samanthula G. Liquid chromatography/tandem mass spectrometry study of forced degradation of azilsartan medoxomil potassium. Rapid Comm Mass Spect 2015; 29: 1437-1447.

8. Madhuresh K, Sethi, Rawat VS, Thirunavukarasu J, Yeramalla RK, Kumar A. Related substances of azilsartan medoxomil: Synthesis and characterization. Der Pharma Chemica 2015; 7: 20-28.

9. Gong C, Wang J, Sun Y, Ding D, Zhong L, Zhu M, Sun J, Zhang $X$. UPLC - MS/MS for the determination of azilsartan in beagle dog plasma and its application in a pharmacokinetics study. Asian J Pharm Sci 2015; 10: 247-253.

10. Sreenivasulu J, Venkata Ramana P, Sampath Kumar Reddy G, Nagaraju CV, Thirumalai Rajan S, Eswaraiah S. A Rapid Novel HPLC Method for Estimation of Eight Related Compounds in Azilsartan Kamedoxomil and Identification of Degradation Compounds by Using LCMS. J Chrom Sci 2015; 53: 1463-1474.

11. Gorla R, Raju V, B Sreenivasulu, N Sreenivas, Srinivas NK Sharma Kumar H, Korupolu RB. Development and Validation of HPTLC Method for Estimation of Azilsartan Medoxomil in Bulk and Pharmaceutical Dosage Forms. Int J Pharm Pharmc Res 2015; 2: 146-153.

12. Baker WL, Nigro SC, White WB. Efficacy of azilsartan medoxomil with chlorthalidone in hypertension. Expert Review of Cardiovascular Therapy. 2014; 12: 791-798.

13. Padmalatha H, Anupama V, Parijatha B and Rama K. Spectrophotometric estimation of chlorthalidone in pharmaceutical formulation using MBTH and FC reagent. World J Pharma Pharmac Sci 2013; 3: 1433-1440.
14. Niraimathi, Suresh, Kumar. UV spectrophotometric methods for the estimation of chlorthalidone in bulk and oral dosage form. Indo American J Pharma Res 2013; 3: 7160-7167.

15. Singh B, Patel DK, Ghosh SK. A reversed-phase high performance liquid chromatographic method for determination of chlorthalidone in pharmaceutical formulation. Int J Pharm Pharm Sci 2009; 1: 24-29.

16. Herráez-Hernández R, Campíns-Falcó P. Chromatographic separation of chlorthalidone enantiomers using $\beta$ cyclodextrins as chiral additives. J Chrom Bio Sci App 2000; 740: 169-177.

17. Tadiboyina S, Bannimath G, Inturi BK. Enantiomeric separation and quantitative Estimation of chlorthalidone enantiomers by Chiral ultra -fast liquid chromatography. Int J Res Pharm Chem 2015; 5: 361-367.

18. Fleuren HL, Van Rossum JM. Determination of chlorthalidone in plasma, urine and red blood cells by gas chromatography with nitrogen detection. J Chrom 1978; 152: 41-54.

19. Ervik M, Gustavii K. Application of the extractive alkylation technique to the gas chromatographic determination of chlorthalidone in plasma in nanogram quantities. Anal Chem 1974; 46: 39-42.

20. Jiri V, Kveta K, Eva T. Rapid Supercritical Fluid Chromatography Method for Separation of Chlorthalidone Enantiomers. Anala Lett 2013; 46: 2860-2869.

21. Walid M. Ebeid, Ehab F, Elkady, Asmaa A,El-Zaher, Ramzia I. El-Bagary, Gabor P. Spectrophotometric and Spectrofluorimetric Studies on Azilsartan Medoxomil and Chlorthalidone to Be Utilized in Their Determination in Pharmaceuticals. Anal Chem Ins 2014; 9: 33-39.

22. Sravani P, Kumar SR, Duganath N, Devanna N. Method development and validation for the simultaneous estimation of azilsartan and chlorthalidone by RP-HPLC in pharmaceutical dosage form. Int J Pharm Sci 2014; 4 : 725.

23. Kasimala MB, Bikshal BK. Reverse phase-HPLC method development and validation for the Simultaneous estimation of azilsartan medoxomil and Chlortalidone in pharmaceutical dosage forms, J Atom Mol 2012; 2: 117-126.

24. Naazneen S, Sridevi A. Stability-indicating RP-HPLC method for the simultaneous estimation of azilsartan medoxomil and chlorthalidone in solid dosage forms. Int $\mathrm{J}$ Pharm Pharm Sci 2014; 6: 226.

25. Sunitha N, Marihal SC, Sushma TS, Venu A, Rao BN, Rao BA. Method Development and validation of stability indicating Rp-Hplc method for simaltaneous estimation of azilsartan and chlorthalidone in pure and pharmaceutical dosage form. 2012; 8: 1-5

26. Aher SS, Saudagar RB, Kothari H. Development and validation of RP-HPLC method for simultaneous estimation of azilsartan medoxomil and chlorthalidone in bulk and tablet dosage form. Int J Cur Pharm Res 2018; 10: 21-24. 
27. Shihata MA. Determination of Tramadol in Liver Tissues Using HPLC-DAD. J Anal Bioanal Tech 2016; 9: 397.

28. Chandran S, Rajarathinam XSR, Kalaiselvan A. Simultaneous Quantification of Drospirenone, Ethinyl Estradiol and Levomefolate by Stability Indicating RPHPLC Method. J Anal Bioanal Tech 2018; 9: 408.

29. Aleixa Do Nascimento P, Kogawa AC, Salgado HN. Development and validation of an innovative and ecological analytical method using high performance liquid chromatography for quantification of cephalothin sodium in pharmaceutical dosage. J Chromatogr Sep Tech 2018; 9: 394.

30. Mohiuddin TM, Islam MD, Latif A. Analytical method validation of rp-hplc method for simultaneous estimation of levonorgestrel and ethinylestradiol from combined drug product. Acta Chim Pharm Indica 2018; 8: 128.

31. Dutta M, Wakode S. A RP-HPLC Method for Estimation of Tramadol $\mathrm{HCl}$ and Chlorzoxazone in Tablet FormulationValidation. Anal Chem Ind J 2018; 18: 127.

32. Jahnavi P, Vartak, Shikha MN Roy. Simultaneous determination of amlodipine besylate,olmesartanmedoxomil and chlorthalidone in pharmaceutical preparations using validated,LCMS compatible RP-HPLC method. Analy Chem Ind J 2015; 15 : 111-116.

33. Spadaro A, Lorenti M, Zasa G, Rao M. Development and Validation of a New Ultra-fast HPLC Method for Quantification ofLevofloxacin in Rabbit Aqueous Humour: Application to a Pharmacokinetic Study. Pharm Anal Acta 2018; 9: 12.

34. Divya A, Vishwanadham Y, Mounika. Development and Validation of RP-HPLC Method for Simultaneous Determination ofDiclofenac Sodium and Eperisone Hydrochloride in Pharmaceutical Dosage Form. Pharm Anal Acta 2017; 8:6.

35. Meng T. Development and validation of an Enzyme Linked Immunosorbent Assay (ELISA) for gentamicin quantification in dried blood spot samples. Asian J Biomed Pharmaceut Sci 2019; 9: 10-15.
36. Vijaya P, Godse, Ashok V, Bhosale, Yogesh S, Bafana, Dhanaraj D. Borkar Stability-indicating HPLC method for simultaneous determination of metoprolol succinate and hydrochlorothiazide in combination drug products. Int $\mathrm{J}$ Chem.Sci 2009; 7: 1733-1745.

37. Desireddy B, sowjanya NG, kumara LT, Hariteja K, Gopaiah, Yehoshuva P, S Brahmam. Development and validation of RP-hplc method for quantitative analysis of simvastatin in pure and pharmaceutical formulations. Int $\mathrm{J}$ Chem Sci 2012; 10: 1583-1590.

38. Elsadig HK, Abdalfatah MB. Comparative Study for the Analysis of Cefixime Trihydrate and its Degraded Products by Two RP-HPLC Methods, One its Official and Other Developed Validated Method. Mod Chem Appl 2017; 5: 2.

39. Chandran S, Xavier Rajarathinam SR, Kalaiselvan A. Simultaneous Quantification of Drospirenone, Ethinyl Estradiol and Levomefolate by Stability Indicating RPHPLC Method. J Anal Bioanal Tech 2018; 9: 1-5.

40. Dongala T, Palakurthi AK, Velaveni KK, Katari NK. Development and Validation of RP-HPLC Method for Simultaneous Determination of Diclofenac Potassium and its Process Related Impurities in Solid Oral Dosage Form. J Chromatogr Sep Tech 2018; 9: 6.

41. Rekha P, Shree P, Bhargav Y, Reddy GR. RP-HPLC Method Development and Validation of Valsartan in Bulk and its Tablet Dosage Form. J Biomed Pharm Sci 2019; 2: 1

\section{*Correspondence to}

T. Hemant Kumar

Department of Pharmaceutical Analysis and Quality Assurance Vignan Institute of Pharmaceutical Technology

Visakhapatnam

India 